\title{
Eliminating Poverty Through Educational Approaches-The Indian Experience
}

\author{
Mohamed Buheji ${ }^{1}$ \\ ${ }^{1}$ International Inspiration Economy Project- Bahrain \\ Correspondence: Mohamed Buheji, International Inspiration Economy Project- Bahrain. E-mail: buhejim@gmail.com
}

Received: June 24, 2019 Accepted: July 15, 2019 Online Published: July 23, 2019

doi:10.5539/res.v11n3p32 URL: https://doi.org/10.5539/res.v11n3p32

\begin{abstract}
This empirical paper studies the different approaches of India in speeding-up education spectrum to eradicate poverty. The research focuses on means for transforming poverty education formula towards 'Capacity vs Demand' rather than 'Supply vs Demand' which would help to improve the quality of the education delivered to the poor with minimal resources.

The research involves a thorough descriptive analysis of India's poverty elimination schools, or its educational approach means, through using observation as a tool. The researcher reviews the current Indian approaches that could overcome the unique barriers of poor quality education. Six types of educational approaches are evaluated in relevance to their capacity to deliver 'lifelong learning', 'learning by doing', and 'self-sufficiency', besides the 'assets of wealth' of the poor. These variables are taken in relevance to the poverty areas where the educational setup are explored. The paper concludes with recommendation about the level of educational focus need to improve the quality of education outcome in relevance to poverty elimination.
\end{abstract}

Keywords: educational approaches to the poor, underprivileged education, poverty elimination, social change, poverty-related education, innovative education solutions, education in India

\section{Introduction}

Nelson Mandela once said, "Education is the most powerful weapon which you can use to change the world". When children in the world and specifically in the mostly populated emerging economy country as India get educated, they can contribute significantly to both the national and international progress. Hence, education is the best answer to poverty and its related issues, like child labour, or early marriage. (Suneja, 2015)

Studies show that more than 171 million people could be lifted out of extreme-poverty, if their children get the basic education that would ensure effective communication of reading and writing along with some science and math. This means we would notice an immediate $10-20 \%$ drop in the world extremely poor individuals. Absolute poverty could be reduced by $30 \%$ from learning schemes as per a study outlined by the Education Commission. Kulild (2014).

A recent Global Partnership for Education (2019) study announced the results of a global survey that show that investing in education increases the earnings of the poor by roughly $10 \%$ per each additional year of schooling. For each $\$ 1$ invested, in an additional year of schooling earnings increase by $\$ 5$ in low-income countries and $\$ 2.5$ in lower-middle income countries.

Educational attainment explains the main difference in growth rates between countries as India and the Sub-Saharan African countries, which were continuing to widen from 1965 till 2010. From studying the Indian success story, we could visualise that in 2050, the GDP per capita in low-income countries would be almost $70 \%$ lower than today, if we could guarantee that all children would get the basic education and essential lifelong learning skills.

\section{Literature Review}

\subsection{The Challenge of Rural Vs Urban Education in India}

Ending poverty requires that the rural and slums areas poverty cycle be controlled and then eliminated. One of the most proven basic controls of poverty is equipping the poor with education. For a country as India, this means more than 800 million who are living in the countryside and in the rural areas of India's out of the total 1.25 billion people need to have appropriate basic education. The rural education services would be more important if we count that at least 216 million Indian are still below the official poverty line with a high increase of migration of such groups to the cities. Suneja (2015). With the slowing down of the world economy in general, the urban economy is expected to slow down in India. The rural 
schools and education system will, therefore, be expected to develop more means to survive and accommodate more coming children; without much dependence on the government programs.

Agriculture is still the largest employer in rural areas. Of the total rural households (90.2 million), over half (57.8\%) are involved in farming. Therefore, many educational efforts need to focus on where farmers and their family work and live. The way education delivered to such communities needs to be creative and minimise the cycle of learning that depends on urban-based educational resources. This means we need to go to the grassroots of such farmers' life and exploit the opportunities that would differentiate their learning outcome. This can be done only through civil society non-government agencies (NGOs) which have been and can play a much larger role in this learning cycle.

In order to link education to socio-economic issues of the poor, we need to first look closely into the salient features of their life commitments and lifestyle and what are the actors influencing this situation. Having, for example, an educational program that would transform child-labour to part-time farming would ensure the poor maintain their minimum earnings while they keep their children in education. Knowing that the income of their farmers is less than the US \$120 per rural household means we need to enhance the profit margin of the family if we want to keep their children in education programs.

\subsection{Requirements of Education in Poverty Areas}

Achieving realised development and prosperity in India is not just about better farming development, it is about holistic educational packages or programs that would facilitate more entrepreneurship opportunities for the poverty villages, the slums and those even living on the footpaths or in railway stations.

Studies show that the tribal areas in general lag 20 years behind the development of the general population. Still, there are no clear educational packages that would break the poverty of the tribal children, or prevent them from the risk of becoming locked into the poverty cycle.

Having a resilient rural India economy, as Gandhi dreamed of, where people have dignified livelihoods; remains a transformative agenda, that India needs to pick-up on, through innovative solutions. Despite the tremendous success, getting children into school since 2000, almost 60 million children are still out of school, and the decline in out-of-school children has stagnated. The children still not in school are the most marginalised and "suffer" from multiple marginalisation factors and poverty-related issues stagnates in such community. In order to minimise such cases for the next generation, more planned simple educational interventions are expected and are necessary.

\subsection{Importance of Education to Poverty Elimination}

Studies show that any emerging economy country understands the benefit-cost ratios; it would consider education to be the smartest investment. Now we know that for each US \$1 invested for schooling in low- and middle-income communities, we would ensure that more student would be on track to gain basic education and would have a higher probability to finish the high school level. Without such investments or specific solutions to replace such influence, the progress toward ending extreme poverty in India would slow down. Suneja (2015), Kulild (2014).

UNESCO policy study paper shows that the global poverty rate could be more than halved if all adults completed secondary school. Yet, new data from the UNESCO Institute for Statistics (UIS) show persistently high out-of-school rates in many countries. Projections suggest that programs that would address adequate quality education suitable for each culture would help to minimise poverty-related diseases, including malaria and AIDs, besides it would improve the family livelihood. Opportunity., E. C. (n.d.).

Education can be the most effective tool to tackle large-scale poverty entrenched in various parts of India. Children who receive holistic quality education are enabled and empowered to grow up into mature, skilled and qualified adults who are eligible for picking up employment or launch their own enterprise.

Recently the newly elected Prime Minister of India Narendra Modi quoted saying "This is an era of knowledge. This is the only potent route to fight poverty. We have to review our commitment to education." SavetheChildren (2017), Suneja (2015), Business Today (2009).

For an emerging and developing country like India, development and upliftment of needy and deprived children can drive the progress of the nation. Education is the key to several issues that magnified due to poverty; such as healthcare, population control, unemployment, besides human rights. Business Today (2009) published that educated individuals are more likely to escape the traps of economic and social despair. On a larger scale, the rewards of individuals getting educated in India found to flow into the entire community, which in turn can have an impact on the entire nation. (Suneja, 2015).

Khwaja (n.d.) confirms that an educated community can progress far better as they can achieve better health and robust economic independence. It can see higher levels of home ownership, entrepreneurial activities and improved 
infrastructure. All this adds up in enabling communities to come out from the quagmire of poverty.

\subsection{Investing in Selective Poverty Elimination Education}

Instead of waiting for the Indian government to develop financially supported schemes to covers the extreme poverty areas, this paper investigates the alternative of selective styles of poverty elimination education, based on tested models. Selective education means we need to develop frameworks and formulas that help to deliver better learning cycles that would reach those children who are disadvantaged due to poverty, instead of waiting for investment from the government to close such gap, which might take a while.

A new research analysis from Nobel laureate economist James J. Heckman finds that early high-quality education has the power to lift multiple generations out of poverty. This new research builds on the evidence showing the importance of a child's earliest years when the brain develops rapidly, laying the foundation for future behaviour, health and learning. Thus investing early in education as per Heckman ( ) would improve the early childhood experience of the poor students. Education found to reduce the incidence of anti-social behaviour and to break the cycle of poverty.

To help India grow economically, then nothing will work better than helping poor children gain selective quality education suitable for their needed competitiveness. Thus this selective quality education goes beyond just donating, for example, materials for poor children education programmes, or paying their tuition from a trusted children's charity. Buheji (2019d) mentioned how selective education provides the best route out of future poverty and inequality. Focusing on the girls' education would help to minimise early child marriage and would improve family planning, besides reducing the maternal deaths.

Selectively empowering the poor by giving them access to information, lifelong learning, coaching and counselling will amplify their possibilities to succeed with differentiation and would prepare them to hold jobs or create jobs or businesses. The targeted selective education should make poor children more confident, give them chances to learn from others and allow them to earn a good living to help their children to live a better life. Such education would be an empowering tool to equip the child or the youth to change the conditions they live in, by taking early actions towards using opportunities around them. Buheji (2019d).

Since the international community has set 2030 as the date for attaining quality secondary education for all, the gap between what young people want, demand, and believe they have and what they can actually access will grow even wider. The costs of this learning crisis - unemployment, poverty, inequality, and instability - could undermine the very fabric the socio-economic status of any community. Opportunity., E. C. (n.d.).

\subsection{SDG of Poverty-Related Education and Wealth Creation}

The Sustainable Development Goals (SDGs) encourage the integration of education services that give children the skills of current and future life. Education in poverty areas also plays as a catalyst for different SDGs, since through education we would ensure cross-generational connectedness while resolving household related issues of primary needs as the availability of: water, food, house, communications, energy, jobs and health.

UNESCO has prepared various papers on poverty eradication within its fields of competence and decided to approach such an issue through a series of projects.

During the World Education Forum held in Dakar in April 2000, the international community underscored the need to eradicate extreme poverty and gave its collective commitment to work towards this aim through education, Kulild (2014). Not only is education important in reducing poverty, but it is also a key to wealth creation. Within this context, one of the pledges of the Dakar Framework for Action: "to promote - Education for All (EFA) policies within a sustainable and well-integrated sector framework linked to poverty elimination and development strategies". Buheji (2019a, 2019b).

The role of education is found to be the process which non-financial wealth can be discovered or exploited. This requires a type of education through which even the most impoverished children could create achievements based on their efforts to do projects with learning theoretical to break the cycle of poverty — Khwaja (n.d.).

Hence, by ending the cycle of poverty through education, we could create a mindset for the poor to appreciate his natural, physical, social and knowledge capital wealth. The selective education process would be like an intervention that would help trapped generations in poverty with limited or no resources to see opportunities by different approaches. The outcome of selective education should help to build resources or connections. Payne (2005) mentioned that through education, we would ensure that we would eliminate generation poverty and alleviate situational poverty. Education enhances social mobility where poor students can become more frequently wealthier or achieve higher income than their parents. 


\section{Methodology}

This paper follows field observations research which correlates the researcher observation of the ongoing educational approaches and practices in India, followed by the government and many NGOs to eliminate or eradicate poverty through educational services. The research methodology targets to address the purpose of this observational study where the educational means in poverty areas are explored from socio-economic perspectives.

In relevance to the literature review, the process of eradicating poverty in India through education is being explored through field visits and projected on the type of condition of poverty. The direct observations of the way education approaches are delivered in different setting environments and in different India provinces conditions are collected through direct field visits. The cases for the types of observations follow naturalistic, or nonparticipant observations where the researcher has no intervention on the investigated educational environments. Therefore, a procedure of studying the behaviours that are needed for poverty elimination education is followed.

As a naturalistic observation, the researcher did not attempt to manipulate the variables around the poverty elimination education, but focused instead on appreciating what are the behaviours needed to eradicate current and future types of poverty. The type of poverty area is diagnosed against its type of exploited wealth and opportunities that are supposed to be of focused priority during the learning cycle. Type of programs needed is then specified based on the primary collected data.

The observations are then filtered in the findings stage to exploit what would make the 'poverty and the underprivileged education formula' goes towards selective quality education; i.e. an education that is focused towards 'Capacity vs Demand' rather 'Supply vs Demand'. This means creating a transformation that would help the poverty community children to have 'quality education' with minimal resources and minimal drop-outs.

\section{Data Collection}

\subsection{Type of Data Collected}

The field observations collected from the different schools, or various educational means in poverty and the underprivileged areas were possible by the collaboration of with different Indian dedicated NGOs; in Mumbai, Nashik, Goa and Assam, during the months of November, 2018 till June 2019. The observations focused on the Indian approaches targeting to speeding-up of the efforts to eradicate poverty, through selective education alternatives for out-of-school children. The observations points focused on the ease of access to schooling approaches. Despite the learning of each outcome of each approach was observed, the researcher founded that reporting such data is beyond the scope of this paper.

The approaches were evaluated in relevance to:

a. The capability of breaking barriers of the poor reaching the education program.

b. The ability of the approach of building lifelong learning skills that would ensure both poverty elimination and poverty prevention.

c. The suitability of the approach to the conditions of the poor.

d. Whether the approach has 'learning by doing' or 'self-sufficiency' education.

The benefits of each school were also collected, but without exploring more the types of schools under each approach. i.e. there are many types of schools and classes delivery in the slums areas, depending on the type of the area and availability of spaces and funding. Also, micro-financed rural areas schools such as 'Grameen Bank' supported schools were ignored, as it is beyond the scope of this paper.

The main general note of observation is that not all the approaches have the same focus. i.e. Some approaches as the government and semi-government schools in the rural areas, focus on improving literacy rates among the underprivileged. Other approaches target mainly to equip the children with basic reading and writing capability with some basic math to manage life essentials. We can see clearly this in approaches in the 'School on the Wheel' and some slums 'Door Step Schools'. And there are other types of approaches which are brought by the innovative social entrepreneurs that give the underprivileged child the advantage of disruptive education that would compensate to the limitations of resources that influence or delayed their overall development.

\subsection{Approaches of Indian Way in Speeding Education to Eradicate Poverty}

The following approaches do not cover all the type of approaches playing a role today in India's efforts to eradicate poverty. Approaches as home teaching, education through micro-credits, education focused on the poor access to ICT networks could not be verified, or field visited, however, they exist to a limited scale, despite not being reported as part of the data collection. 


\subsection{1 'School on the Wheel' Approach}

Schools on the wheel is an approach now spreading in many places in India and through a variety of NGOs. The approach addresses the gap in the large population of illiterate children number of India's urban areas. The researchers experienced first the school in the wheel in Nashik, where the NGO delivering the project target to address a specific tribal community, called 'Sayed community' which more than six generations did not attend any school and mostly been working as stunts in Bollywood. Later the researchers observed the same approach in different cities in India, specifically in Delhi and Mumbai. This approach address specifically urban areas needs where parents are resisting to send children distances of more than 1 kilometre away from the village, or the children being of mobilising families where parents are moving home based on the type of job, or source of family income; as working as labour in construction sites.

This type of approach addresses the need for an immediate solution, or means of education and learning services that can be delivered on site, to mitigate the risk of having more marginalised children in India that are receiving little or no education. Alternatively, addressing specific children of community high dropout rates. Figure (1) shows the field visits to school on the wheel approach in Nashik.

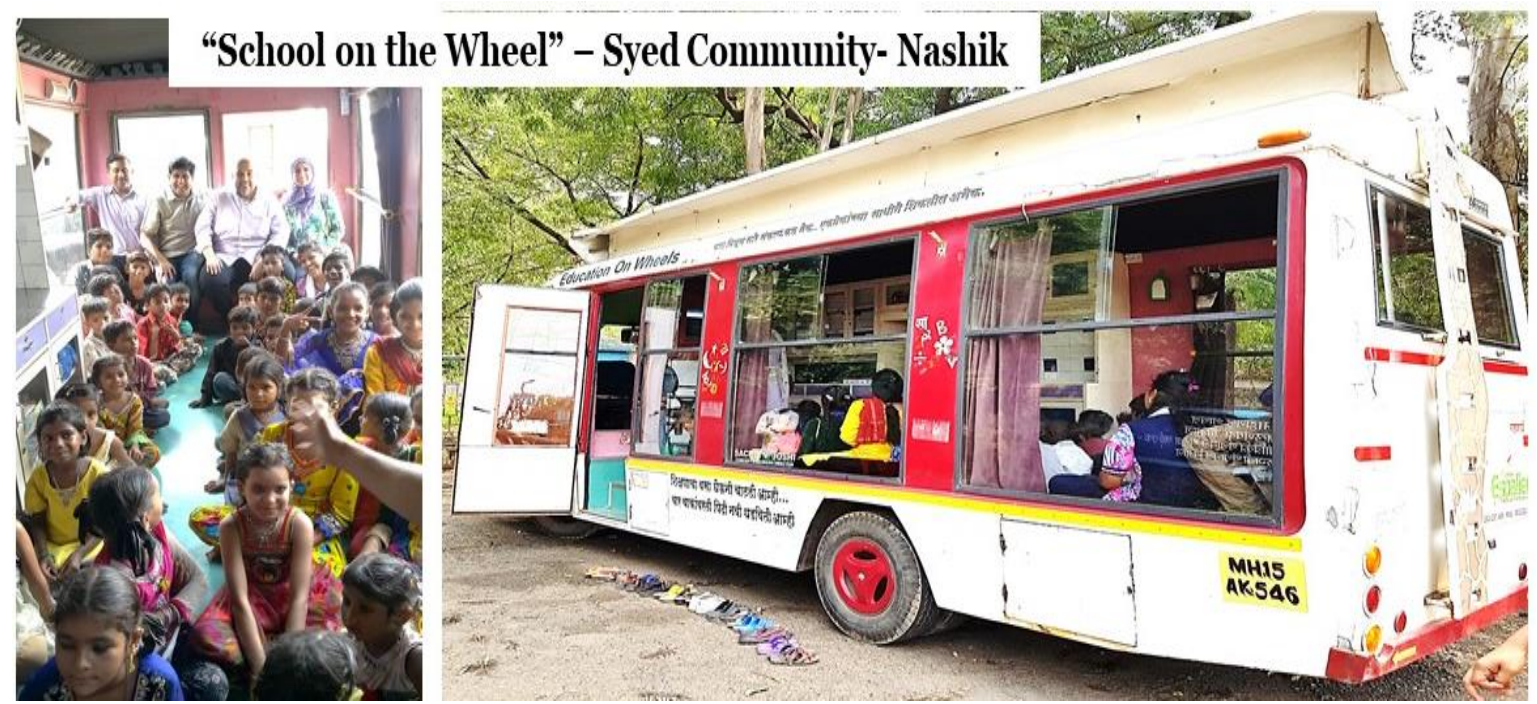

Figure 1. Illustrates School on the Wheel parking in a shaded area near the tribal huts of Syed Community

\subsection{2 'Door Step Schools’ Approach}

This approach targets to totally break the barriers for poverty areas children who cannot come to school, to be reached by semi-structured school programs delivered by the NGOs. This 'Door Step School' approach usually starts by going from door to door, offering free education services to the poor and the marginalized, then as the number and the trust of the families grows usually the Door Step School takes a settled building from the municipality or donated by sponsors near the slums.

The first known 'Door Step School' was started in Mumbai in 1988, by Rajani Paranjpe and Bina Lashkari in Mumbai, India. Since then this approach spread all over India, and even copied by many leading international NGOs, in different countries with similar issues of poverty, where educational access to the poor and marginalized is still a challenge. Despite of the many efforts undertaken by the government and leading Indian private enterprises and NGOs, there are about 1.7 million children might benefit from such an approach.

The 'Door Step School' approach usually addresses the challenge of the slums where there are many children drop-out and with many challenges of completing their education through formal government schools, or deprived of being to coop with education programs that don't realise the needs and the limitations of the families where parents can't coop with daily labour and taking care of younger siblings while at work.

The uniqueness of the 'Door Step School' approach, compared to other observed approaches in this study, is that have more capacity in bridging the gap towards the SDGs and the Indian government educational plans in relevant to the underprivileged and enhancement of sustained schools' enrolment rates. Figure (2) shows visits of the researcher to two different slums 'Door Step School' programs in a Mumbai and Assam slums. 


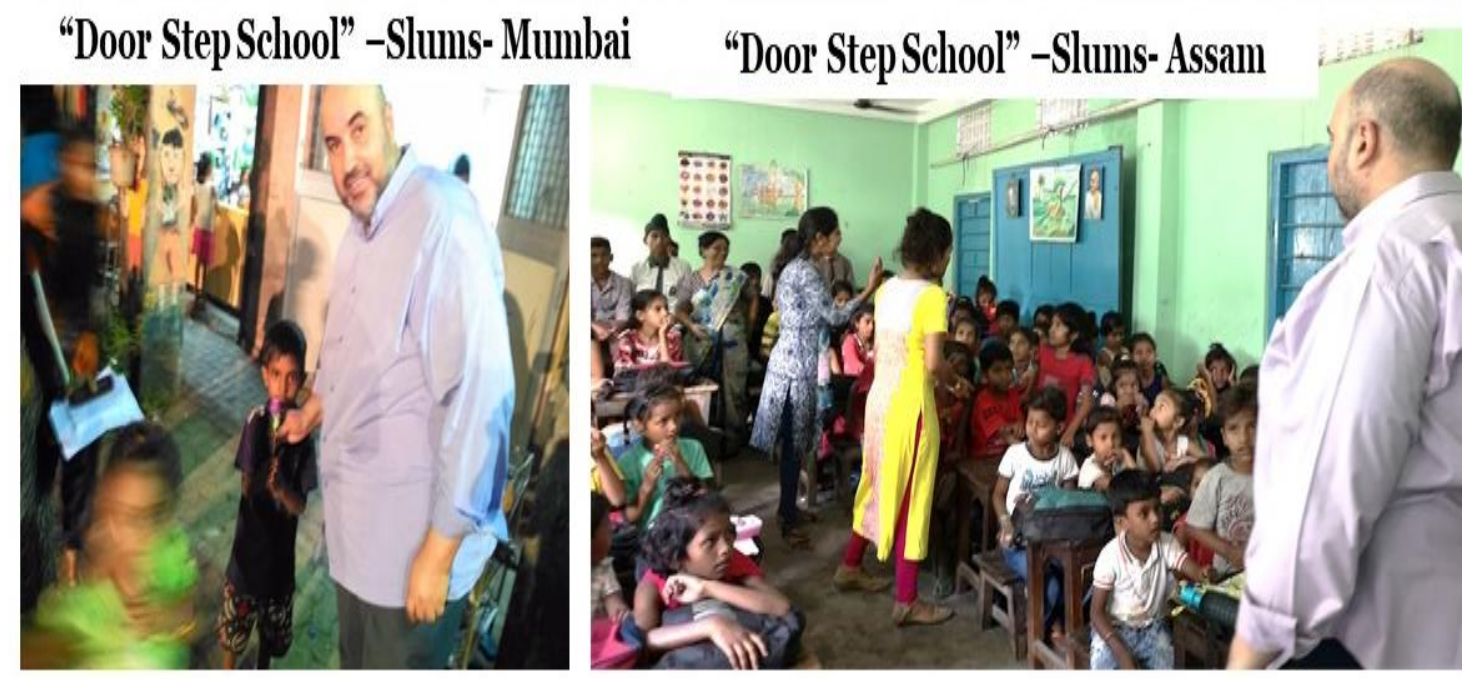

Figure 2. Illustrates 'Door Step School' visits on two different slums areas in Mumbai and Assam

\subsection{3 'Government Supported School' Approach}

Rural education in India is of importance to the government as the majority of India's children lives in villages. Kaur (2019) report that despite that the number of rural students attending schools is rising, more than half of the students in fifth grade are unable to read a second-grade textbook or are not able to solve simple math problems.

The observation of the visited rural schools is that they are not evenly distributed as per the population and areas. For example, not every village have schools. The quality access to suitable education is creating major concern in rural schools. Such government supported rural schools approach found to have fewer committed teachers and lack of in proper textbooks. Figure (3) show an example of how government-supported rural schools in India are mostly overly packed with students, with high students: teacher ratio.

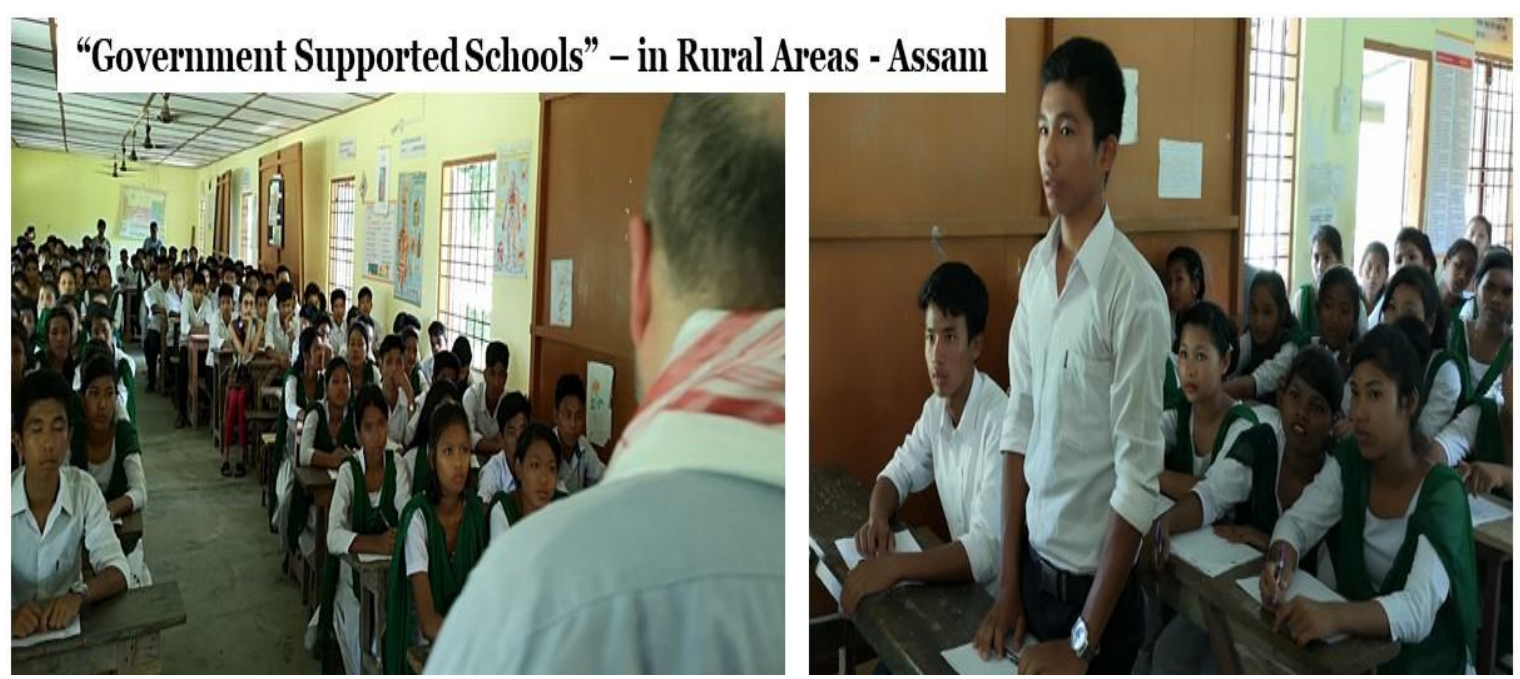

Figure 3. Illustrates Government Supported Schools in rural areas in Assam, where the poor can afford to bring their children to formal education and the school classes would be overcrowded 


\subsection{4 'Semi-Government Supported Schools' Approach}

Semi-government supported schools found to be physically not as good as fully supported schools. Such schools still suffer from high students drop-out. Such schools found to be weak in English teaching.

The other observation noted in such schools is that the education curriculum is note related to the rural type of culture, traditions and values. The teaching does not take account of students' inclusion programs, extracurricular classes and different students difficulties of learning.

Bihar. These are innovative and successful examples of schools running in rural India. It is the time to replicate such efforts as our country, and its rural population is very vast, which means one of two stories of these kinds will not make any difference. Instead of this large number of such schools are required in rural India. It is also absolutely mandatory to evaluate the success of the schools and students at every level. Timely assessment will throw light on present problems and achievements. Let us try to build a solution around these problems which will resolve the overall issues of rural education in India.
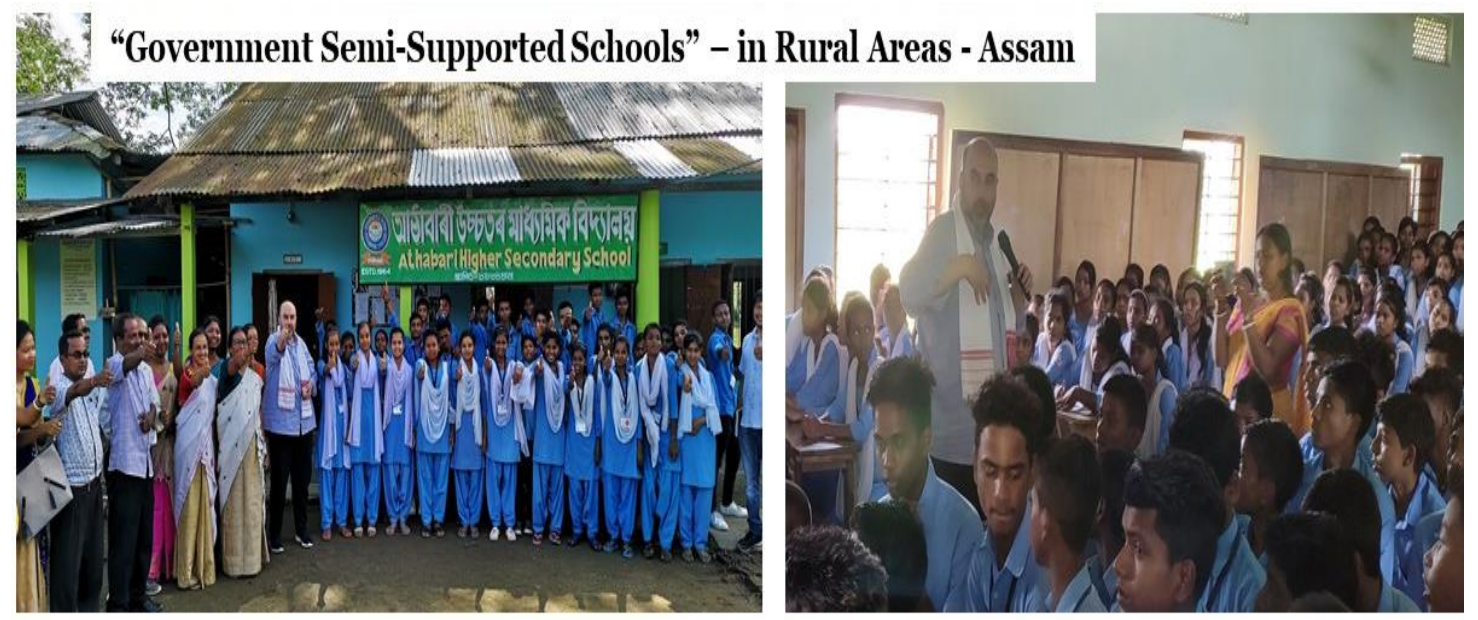

Figure 4. Illustrates Government Semi-Supported Schools in rural areas in Assam, where the school would have very limited resources to deliver formal education

\subsubsection{NGOs Managed Schools}

There are a variety of goals that were observed for the different non-government organisations (NGOs) managed schools in India's poverty community, be it a charity-driven, or a community change-focused organisation. However, one of the main consistent observations was improving students' attendance and continuation of education by focusing on physically get them to the class in the first place. The main differentiation of the NGOs managed approaches, particularly in rural areas and in the slums, is that they have a good high rate of elimination of children drop out, especially those below high school. They are more trusted to convince the families to see alternatives or the positives of keeping the child finish the minimal primary basic education classes.

Many of the NGOs supported educational schemes create services mix to encourage families to make their children attend most days of school as giving financial support, or get food, or receive regular health check-ups. Figure (5) shows the crowdiness of the NGOs fully managed schools, yet with high students' attendance. 


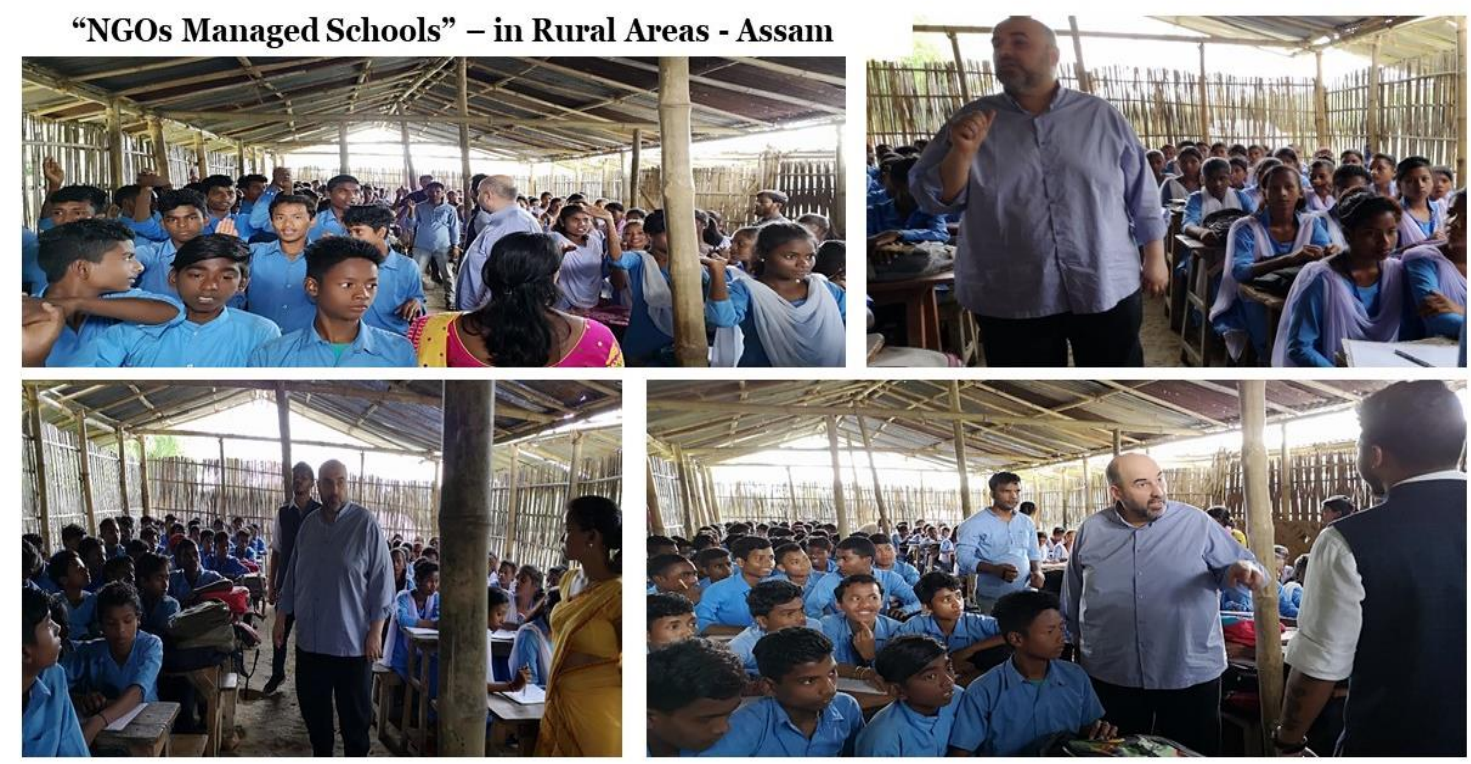

Figure 5. Illustrates NGO fully managed School in rural areas in Assam, striving to deliver formal education with simple construction and overcrowded students

4.2.6 Innovative Disruptive Education (Structured \& Unstructured peer to peer education) Schools Approach (Akshar Model)

Akshar is one of the unique, simple, innovative, disruptive educational approaches that are focused on improving the level of educational outcome delivered to the underprivileged through strong educational initiatives led by the NGOs and social entrepreneurs in India. Akshar target to close the gap of the children from low-income families through building on the unique learning capacities that would help them to coop with life challenges and make a difference. The peer-t0-peer approach and modular learning based on the one to one teaching targets to increase the hit rate of the Akshar students to be unique in both theory and practice. This program is similar to programs experienced by the researcher called 'experiential learning' approach, which was excluded in this study due to its being tested in leading schools and not necessarily address the poor needs. Figure (6) shows the Akshar model delivered in the suburbs of the Guwahati in Assam.

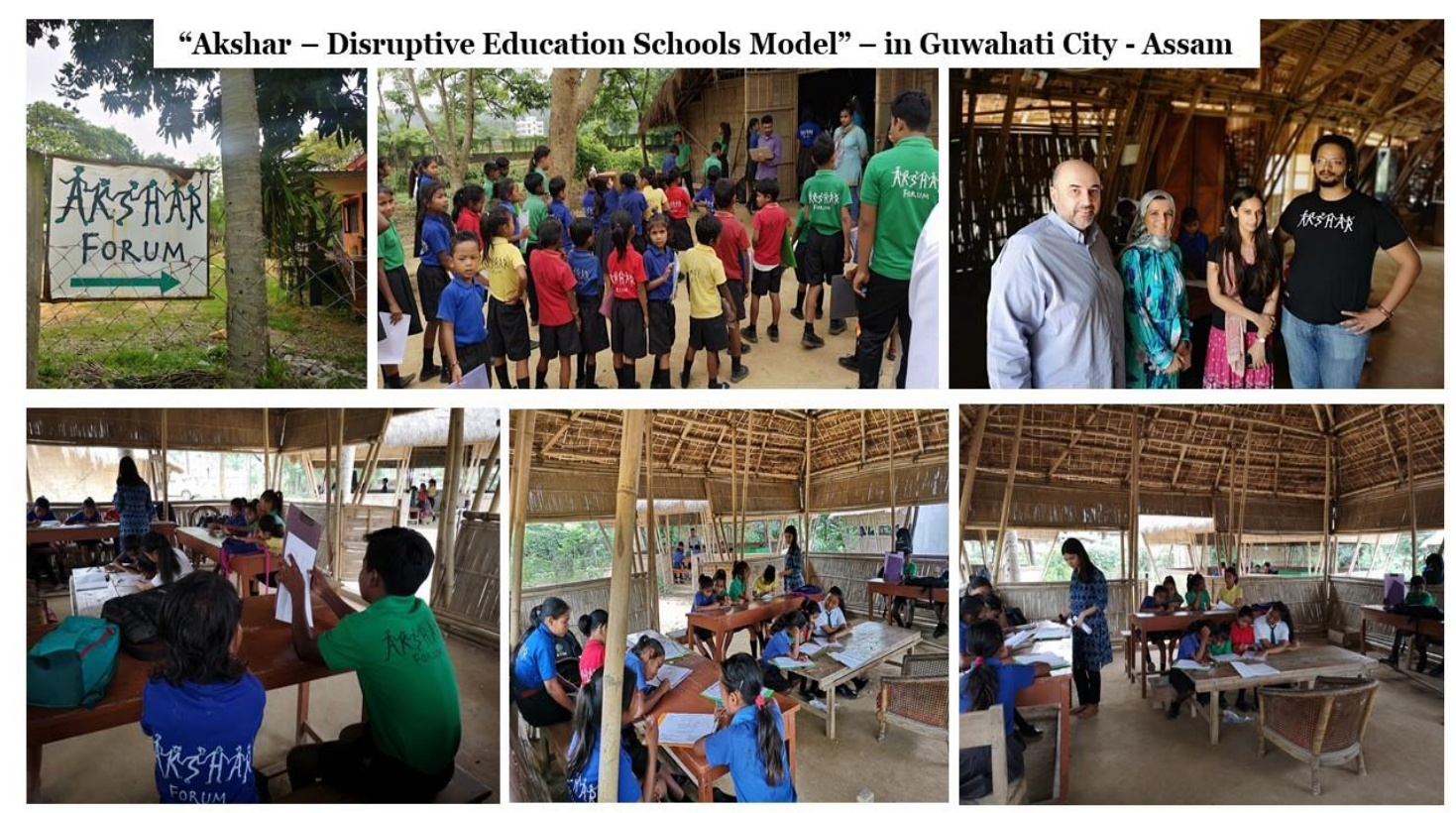

Figure 6. Illustrates one of the Innovative Disruptive Education Model School approach, usually led by Social Entrepreneurs. This model called Akshar is delivered in the Capital of Assam, Guwahati 


\section{Findings}

\subsection{General Findings}

The observed data collected on the poverty elimination educational approaches shows that there are no links between these educational approaches and the wealth of assets of the poverty area served. The data shows there could a link between the approaches and the barriers of the poor towards education.

The finding shows that the approaches have a different level of influence on the lifelong learning skills of the students. Some approaches have more learning by doing educational practices than others. Mainly only one approach, called Akshar, encourage self-sufficiency mindset.

\subsection{Poverty Elimination Educational Approaches and Type of Wealth}

As mentioned in 6.1, the poverty elimination approaches do not seem to have any linkage currently with both the poverty area where the school or the classes are delivered, and the wealth of possible assets that could the poor students could be inspired to use, to change their current situation. In Table (1) we try to link the three variables, re-organised from the scattered field observations to see how to enhance the capacity of the educational services, delivered to the poor by the six different approaches mentioned in this study, to exploit the poor wealth of asset and hidden opportunities.

Table 1. Possible Missing Relations between the Type of poverty area along with the possible assets and opportunities of wealth with the educational Approaches needed

\begin{tabular}{|l|l|l|}
\hline Type of Poverty Area & Wealth \& Focus Priority & Type of Educational Approach Needed \\
\hline Fisheries Areas & $\begin{array}{l}\text { Physical, Natural, Knowledge } \\
\text { Assets }\end{array}$ & $\begin{array}{l}\text {-Door Step Schools } \\
\text {-Home teaching } \\
\text {-Semi-Government Supported Schools }\end{array}$ \\
\hline Agriculture Areas & $\begin{array}{l}\text { Natural, Physical and Knowledge } \\
\text { Assets }\end{array}$ & $\begin{array}{l}\text {-Microcredit Schools } \\
\text {-Semi-Government Supported Schools }\end{array}$ \\
\hline $\begin{array}{l}\text { Remote Areas (areas } \\
\text { between main cities) }\end{array}$ & $\begin{array}{l}\text { Physical and Non-Financial Assets, } \\
\text { then Natural Assets }\end{array}$ & $\begin{array}{l}\text {-Home Teaching } \\
\text {-Microcredit Schools } \\
\text {-Disruptive Learning \& Peer-to-Peer } \\
\text { Schools } \\
\text {-Government Supported Schools }\end{array}$ \\
\hline Mountaineers Areas & $\begin{array}{l}\text { Physical, Natural and Knowledge } \\
\text { Assets }\end{array}$ & $\begin{array}{l}\text {-Missionary Christian Schools } \\
\text {-Door Step Schools }\end{array}$ \\
\hline Slums Areas in Main Cities & Knowledge, then Physical and & $\begin{array}{l}\text {-Slums Schools } \\
\text {-Door Step Schools } \\
\text {-Disruptive Learning \& Peer-to-Peer } \\
\text { Schools } \\
\text { Non-Financial Assets }\end{array}$ \\
& & $\begin{array}{l}\text {-Teaching on the Wheel Schools } \\
\text {-Semi-Government Supported Schools }\end{array}$ \\
\hline
\end{tabular}

\subsection{Influence of Current Educational Approaches on the Poor Mindset}

Since the scope of this paper about the educational approaches that are available in India today to eliminate poverty, one could not undermine evaluating the influence of such approaches on the mindset of the poor. Buheji (2019) mentioned that without changing the mindset of the poor children, we could not guarantee that they would escape from the vicious poverty trap. Therefore, we need a type of education that would change the assumptions, the perception, the attitudes, the behaviours and the reactions of these underprivileged children and youth, in relevance to their possible wealth alternatives and opportunities. Going through the six approaches and their way of delivery, none of them could claim they are directly contributing to this level of mindset change.

To be accurate and precise, Akshar may follow a mild multi-disciplined approach to a certain extent. However, again, all the approaches miss clear programs that would lead to a holistic mindset that would start to see and exploit opportunities around the challenges faced in life. The absence of the multi-disciplined innovative teaching approaches that fit the environment and the condition of the poor condition student in the underprivileged community is actually a serious gap that needs to be rectified if India and similar countries want to reach the SDGs with a competent generation that could see 
the opportunities in the problems. Figure (7) reflects the type of mindset driven education needed by the underprivileged students today, as mentioned in Buheji (2018).

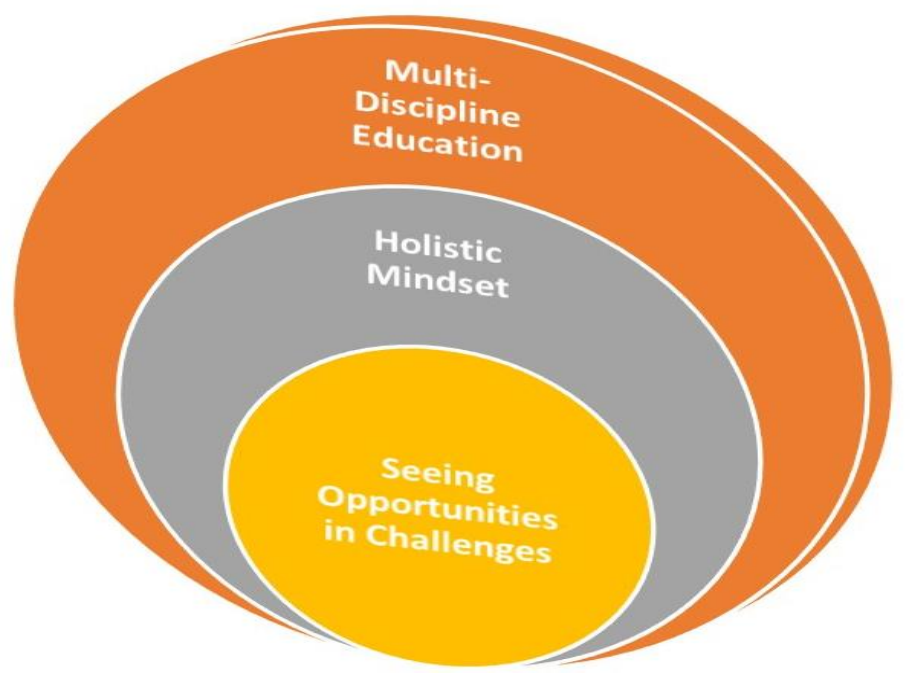

Figure 7. Levels of Mindset Possibilities Needed in the Poverty Elimination Educational Approaches

\section{Discussion}

\subsection{Barriers to the Poor Learning Cycle}

Poverty is a major cause of children not completing their learning, even if they manage to reach educational schemes or attend any school approaches mentioned. In India and similar to many developing and emerging economies countries, the gap in primary school completion rates between the richest and poorest children is more than $30 \%$. A child's village or poverty area condition besides gender, family stability status, health, ethnic and cultural conditions, besides the economic background play a significant role in poor student learning cycle. Without real learning, any underprivileged child will not be able to succeed to go out of his/her trap. (Buheji, 2019a; Suneja, 2015, Business Today, 2009).

\subsection{Importance of Lifelong Learning Skills to Poverty Elimination}

Poverty eradication through lifelong learning skills education is crucial for children of families that live under, or just above the poverty line. Current approaches are doing a great job to help India's government coop with the SDGs goals relevant to both eliminating poverty and improving literacy. However, these approaches do not have the seeds for lifelong learning skills that would help to raise the capacity of the poor for any sudden economic, or socio-economic downturn or natural crisis, like loss of jobs, or decline of business; which would lead to getting back to poverty situation trap again.

The formal education of the poor, often does not help the poor to break the poverty cycle. Teaching the poor to read and write, actually, make them learn more on how to care for their family and how to manage their life essentials, but does not equip them to explore other future opportunities. Developing programs as Akshar approach would help the poor to accumulate lifelong learning skills that would give them the capacity to avoid poverty-related practices and to empower themselves and their family, Khwaja (n.d.).

If people in high poverty areas are educated as lifelong learners, they will be able to climb out of poverty. Being lifelong learners would help the underprivileged students to see their choices and would give them the ability to improve themselves and their surrounding society. Buheji (2019d).

Lifelong learning would make the youth care more curious about the resources around them, and this means they would care more about the managing time and improve the way household are financed. Buheji (2019b).

\subsection{Learning by Doing in Poverty Education}

India's current educational poverty elimination approaches do not practice any 'Learning by doing' practices. 'Learning by doing', 'learning by exploring' and 'learning by trial', found to enhance the students' chances to live a curious life and thus enhance their capacity to achieve despite the limited resources. Buheji (2019b).

'Learning by doing' empower the poor youth mental capacity and minimise their disability in dealing with 'life challenges'. Thus, the poor need to do projects to explore their available and hidden opportunities. Basically, the 'learning 
by experimentation' will trigger a change in the mindset of the poor student. For instance, a person who has the right education might start a business at his community that will employ a few more people. The efforts of few will have an impact on the many.

\subsection{Self-Sufficiency Education \& Its Importance to the Poor}

The observations collected on poverty elimination education approaches do not carry any self-sufficiency skills that would help to raise their capacity in managing income-generating opportunities. With self-sufficiency based education and training, we could enable the poor children and youth to earn independence and see their capability to provide resources for their family, while they are studying. In addition to just earning, with self-sufficiency education, we can build in the mindset of the poor student also get aspiration and clarity for 'life-purposefulness' that would make them more persistent in getting over their personal sufferings and raising their capacity to contribute for the development of the rest of the society. Buheji (2019c).

Self-Sufficiency builds a sense of worth and helps to create total eradication of poverty. Once the poor children have a sense of worth, they would get motivated to improve their education and develop self-confidence to pursue their dreams. Khwaja (n.d.).

With self-sufficiency, the poverty family youth could pursue a better way of life, and target to seek a dream about a job, and become more competent in dealing with risks as overcoming material deprivation. Once self-sufficiency is established, we would have the poor better accessibility to their land ownership, livelihood and cultural commitment. This would ensure community development and effective economic justice.

\subsection{Benefits of 'Door-Step'Slums Schools}

Slums schools as 'door-steps schools', or 'teaching on the wheel', or new schools peer to peer education model as Akshar; all open opportunities to receive better education, health care and dignity-based work. Such education might provide critical thinking, networking and making friends and contacts. This would help to better sharing of ideas and solutions, and thus creating better self-driven solutions to fight poverty.

Such schools help to build social integration, which helps knowledge sharing. Such students can be constructive to manage community meetings to improve living standards.

\subsection{Education as a Means for Appreciating the Wealth Assets}

Wealth creation should be of a significant aspect in education programmes intended to contribute to poverty eradication. Education assists us in identifying the opportunities of the assets visible or invisible. Integration of school education within the economic activities of a community is essential for the effective return of such educational services on the student lives and their families. For instance, in a carpet-weaving village, lessons should also cover various aspects of the carpet industry. In this way, school education would help children to improve traditional trade skills of the village alongside other curricular contents. It would ensure their future employment possibilities and contribute to the (economic) wellbeing of the whole community. Furthermore, the school would not then be alienated from the community, and traditional trades would reinforce learning. Buheji (2019a), Khwaja (n.d.).

For the education system to truly respond to the needs of poor children and to contribute to wealth creation in communities and society at large, it needs to take the issue of poverty into special consideration in the planning of educational services. Essentially, it has to prepare the children to exploit their wealth and heighten the capacity of their rights and responsibilities and enhance their self-confidence to enable them to improve their lives. This means stocktaking of the assets of poor children and their families (a situation, conditions, reasons for poverty, etc.) so that appropriate support can be planned and targeted to them. Buheji (2019a).

\section{Conclusion and Recommendation}

\subsection{Enhancing India's Efforts in Eliminating Poverty Through Education}

India's population in poverty declined to reach below $25 \%$; the effective elimination of poverty through education is becoming more and more difficult. Many underprivileged Indians are increasingly reaching educational access, however still and most probably be at socio-economic disadvantage. Therefore, this research focus on improving the educational approaches for the poorest children in India, based on the collected field observations. The target of this work is to set a new line of research about better mapping of educational access for children in poverty, specifically those in the rural areas and the slums of India.

\subsection{Transforming Poverty Education Towards Capacity vs Demand}

Education supposed to build communication channels that lead the poor child or youth to express their own ideas and have the capacity to create change in their socio-economic status, or solve current or future challenges. To break the poverty 
cycle, poverty education should help to cater to children's diverse needs and even to provide additional support outside academic classes.

Therefore, a framework is suggested to the enhance the current approaches and transform their goals from being services that work just to fill the gap of India to meet the SDG, i.e. playing the role of 'Supply vs Demand', to approaches that work on the formula of 'Capacity vs Demand'. The proposed new formula of 'Capacity vs Demand' would focus on developing programs and schemes that establish a mindset that realises 'lifelong learning' skills, support 'learning by doing' practices, build self-sufficiency behaviours and lead to an appreciation of the wealth of assets available in the underprivileged.

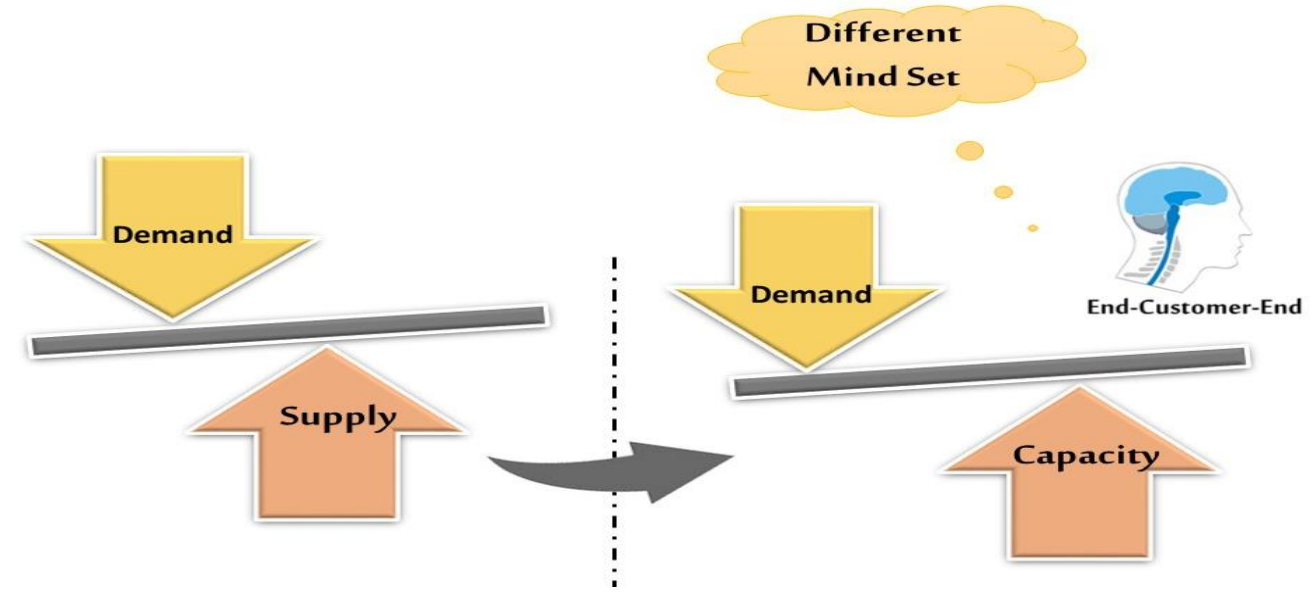

Figure 8. Illustrate the importance of transforming the Educational poverty elimination approaches towards 'Capacity vs Demand'

Through such proposed transformation, poverty elimination education approaches, India can do change management in the mindset of the future coming generation. This means establishing more holistic poverty elimination educational services that would ensure effective socio-economic change.

\section{References}

Buheji, M. (2018). Re-Inventing Our Lives, A Handbook for Socio-Economic “Problem-Solving”. AuthorHouse, UK.

Buheji, M. (2019a). 'Re-designing the Economic Discovery of Wealth' a Framework for Dealing with the Issue of Poverty. International Journal of Economics, Commerce and Management, United Kingdom, VII(2), February, 387-398.

Buheji, M. (2019b). Designing a Curious Life. AuthorHouse, UK.

Buheji, M. (2019c). Poverty Labs- From 'Alleviation' to 'Elimination and then Prevention'. Journal of Social Science Studies, 6(2), 108-122. https://doi.org/10.5296/jsss.v6i2.14684

Buheji, M. (2019d). Shaping Future Type of Poverty - The Foresight of Future Socio-economic Problems \& Solutions Taking Poverty as a Context- Beyond 2030. American Journal of Economics, 9(3), 106-117.

Business Today. (2009). How to end poverty in India,. Retrieved May 1, 2019, from https://www.businesstoday.in/magazine/special/how-to-end-poverty-in-india/story/4055.html

Education, G. P. (2016). 5 ways education can help end extreme poverty. Retrieved from https://www.globalpartnership.org/blog/5-ways-education-can-help-end-extreme-poverty

Global Partnership for Education. (2019). Education Data. Retrieved from globalpartnership: https://www.globalpartnership.org/data-and-results/education-data

Hinteregger, T. (n.d.). Poverty Rate in India. Retrieved from https://borgenproject.org/poverty-rate-in-india-2/

Khwaja, M. (n.d.). Education Alone cannot eradicate poverty, Fair Observer. Retrieved from https://www.fairobserver.com/360_analysis/education-alone-cannot-eradicate-poverty-23320/

Kulild, V. (2014). Role of education in ending extreme poverty -Taking a global lead, , Norad, Carita seminar on the United Nations Sustainable Development Goals, Post-2015 Development Agenda, Oslo, 11th November. Retrieved May 1, 2019, from 
https://norad.no/en/front/about-norad/news/role-of-education-in-ending-extreme-poverty--taking-a-global-lead/

Opportunity, E. C. (n.d.). The Learning Generation, Investing in Education for a changing world-Executive Summary. Retrieved from www.educationcommission.org

Payne, R. (2005). A framework for understanding poverty (4th edition). . Highland, TX: aha! Process, Inc.

Savethe Children. (2017). Eradication of poverty through education in India. Retrieved from Save the Children: https://www.savethechildren.in/articles/eradication-of-poverty-through-education-in-india

Suneja, V. (2015). Why ending poverty in India means tackling rural poverty and power. Retrieved May 1, 2019, from https://www.oxfamindia.org/featuredstories/why-ending-poverty-india-means-tackling-rural-poverty-and-power

UNESCO. (2015). EFA Global Monitoring, Reaching the marginalized Reaching the marginalized. Retrieved from Education for All: https://unesdoc.unesco.org/ark:/48223/pf0000186606

UNESCO. (2015). EFA Global Monitoring, United Nations Educational, Scientific and Cultural Organization. Retrieved from EDUCATION FOR ALL 2000-2015: Achievements and Challenges, EFA Global Monitoring Report.

UNESCO. (2016). EFA Global Monitoring, Education for All, United Nations Educational, Scientific and Cultural Organization. Retrieved from TEACHING AND LEARNING: Achieving quality for all.: https://unesdoc.unesco.org/ark:/48223/pf0000225660

\section{Copyrights}

Copyright for this article is retained by the author(s), with first publication rights granted to the journal.

This is an open-access article distributed under the terms and conditions of the Creative Commons Attribution license (http://creativecommons.org/licenses/by/4.0/). 